\title{
Environmental impact of coronavirus (COVID-19) from Turkish perceptive
}

\author{
Serdar Aydın, et al. [full author details at the end of the article]
}

Received: 19 June 2020 / Accepted: 5 August 2020 / Published online: 13 August 2020

(c) Springer Nature B.V. 2020

\begin{abstract}
COVID-19 was not taken seriously by many of us until the wave hit our countries and impacted daily life routines and travel plans, similar to our responses to climate change. COVID-19 led to a decrease of anthropogenic activities in Turkey, largely due to lockdown. Changes in the air quality index (AQI) were assessed before and during coronavirus. In this study, the authors investigated the changes of AQI for $2.5 \mu \mathrm{m}$ particulate matter $\left(\mathrm{PM}_{2.5}\right)$, a primary air pollutant, as well as ozone, a secondary air pollutant, in Turkey during December 2019, April 2020, and May 2020. Overall, the $\mathrm{PM}_{2.5}$ index improved by $34.5 \%$ by the end of April 2020. However, the ozone index increased from 16.8 to 28.8 by the end of April. The increase in ozone is attributed to the reduction of PM levels, which increased sunlight penetration. Before COVID-19, the AQI for Turkey was categorized as unhealthy for sensitive groups $\left(\mathrm{PM}_{2.5}=103\right)$; however, during the pandemic, AQI fell to lower boundaries of the moderate category by May $2020\left(\mathrm{PM}_{2.5}=56.9\right)$. Changes in municipal wastewater were also assessed. Municipal wastewater quality and hospital waste generation did not change during the pandemic in Turkey. Therefore, we should not expect COVID-19 risks in treatment plant effluents. This study gives confidence to regulators that when strict measures are implemented, air quality can improve.
\end{abstract}

\section{Graphic Abstract}

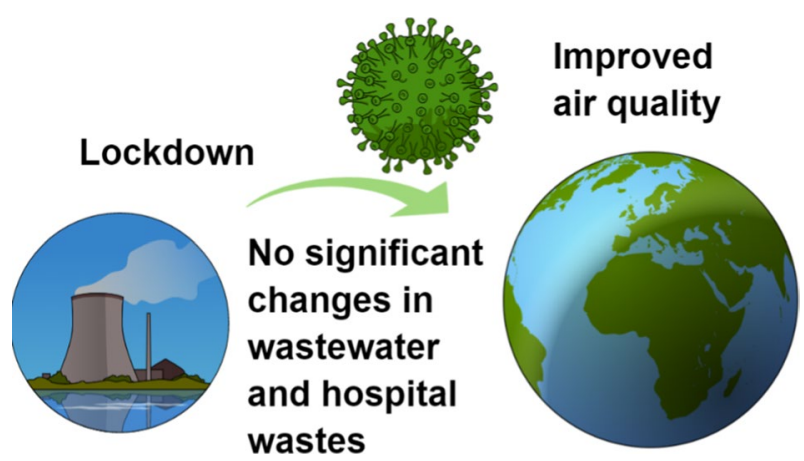

Keywords Public health · Air pollution - Municipal wastewater $\cdot$ Hospital waste Coronavirus $\cdot$ Global pandemic 


\section{Introduction}

In December 2019, a highly infectious and deadly respiratory virus infected humans for the first time; it was named coronavirus disease 2019 (COVID-19). COVID-19 proliferated faster than public health measures could contain it. Scientists have chased the origin of coronaviruses for more than a decade, and found them to be from bats residing in China's Yanzi and Shitou caves (Wang et al. 2018). Coronaviruses are viruses that are covered in small spikes of protein, which look like a crown (Sawicki and Sawicki 1986). There are several coronaviruses; however, only seven have been found to be extremely hazardous to humans, the most popular being severe acute respiratory syndrome (SARS-COV), middle East respiratory syndrome (MERS-COV) (Wong et al. 2015; Cattivelli and Rusciano 2020; Gallardo et al. 2020; Lee 2020), and currently COVID-19 (also known as SARS-COV-2). The latter is more dangerous because it has both MERS-COV and SARS-COV characteristics. Cold weather prevents the fragile COVID-19 casing from drying out, enabling the virus to live between hosts for longer (Banik et al. 2020). At the same time, sunlight UV exposure can affect the housing, which is disarming to the virus, although these seasonal variations are more important for known infections (Shirbandi et al. 2020). Not many are immune to a new virus, though; therefore, it has so many potential hosts that it does not need idle spreading conditions. For this reason, COVID19 was declared a global pandemic by the World Health Organization on March 11, 2020.

Two weeks after China announced its first COVID-19 case, Turkey reported its first coronavirus case. Turkey took immediate actions to combat the pandemic. On January 10, 2020, a science council was established to study and manage COVID-19 cases. This was followed by passenger testing at significant entry points in the country, especially at the airports. On February 3, 2020, Turkey halted all flights from China. In less than a week, when Iran confirmed its first case, the borders between the two countries were closed. On March 12, 2020, schools and universities were closed to reduce the wide spread of the virus. Although drastic measures were enacted, the number of confirmed cases increased exponentially to over 163,000. By May 30, 2020, nearly 4500 deaths had been confirmed in Turkey due to COVID-19 (Johns Hopkins University 2020). There is no doubt that the COVID-19 pandemic has halted the Turkish economy. Istanbul, one of the most visited cities in the world, has empty streets like never before, affecting tourism, which contributed the U.S. \$34.5 billion in revenue in 2019.

To curb the economy from plummeting, the country announced a nearly U.S. $\$ 16$ billion stimulus package. Furthermore, Turkey announced credit payment delays, lowered domestic duties on domestic flights, and canceled the accommodation tax to bootstrap the tourism sector. All these actions depict the direct effect of the coronavirus on the economy. However, little has been documented to show the impact of COVID-19 on other spheres that govern life in Turkey. In this study, the effect of COVID-19 on air quality, municipal wastewater, and hospital waste generation are discussed. The changes in air, waste, and water directly reflect the public health of a given community. This study acts a foundation for future atmospheric and water modes to be constructed after the pandemic.

\section{Methodology}

To study the variations in the air quality index during the pandemic, 20 regions covering different parts of Turkey were analyzed: Adana, Amasya, Ankara, Antalya, Artvin-Hopa Balıkesir, Bolu, Burdur, Bursa, Edirne-Keşan Erzurum, Eskişehir, Iğdır, İstanbul-Ümraniye, İstanbul-Kağıthane, İstanbul-Esenyurt, Kayseri Kocaeli-Gebze, 
Kocaeli-Alikahya, Konya, Ordu, Rize, Sakarya, Samsun, Sivas, Tekirdağ- Çerkezköy, and Trabzon. The study covered a period from December 2019 to May 2020. The study covered PM, a driver of air quality, and tropospheric ozone, a leading cause of smog. For wastewater treatment plants, the study covered Sakarya and Lüleburgaz regions. Changes in the flowrate, chemical oxygen demand (COD), and total suspended solids (TSS) were studied. Hospital waste data were based on Sakarya hospitals - one of the more affected regions in Turkey during the pandemic. Data were presented in the form of maps and graphs. All air quality data were obtained from the online portal of the Ministry of Environment and Urban Planning, Turkey (http://havaizleme.gov.tr/). ArcGIS Version 10.3 was used to generate spatial maps; maps were generated using Osra's and Kajjumba's (2020) approach.

\section{Air quality}

Air quality has become one of the benchmarks to determine public health. Air quality is determined through air pollution. Air pollution is the introduction of chemicals that threaten life; when such chemicals are inhaled, the chances of getting lung diseases, heart diseases, and cancer increase. In 1952, the Great Smog of London was responsible for 4000 to 12,000 deaths (Polivka 2018). This led to the birth of air quality legislation in different parts of the world. Air pollution is responsible for over ten premature deaths every three hours in Turkey (Temiz Hava Hakk1 2019). The Turkish authority enacted legislation to reduce emissions from industries and transportation, give incentives for cleaner technologies, and reduce emissions from open burning. Air pollution can occur naturally (through volcano eruptions and wildfires) or by anthropogenic activities. The latter is the main driver of air pollution. Primary air pollutants include volatile organics (VCs), carbon monoxide, nitrogen oxides $\left(\mathrm{NO}_{\mathrm{x}}\right)$, sulfur dioxide, lead, and particulate matter $(\mathrm{PM})$. Secondary pollutants include sulfuric acid and ozone $\left(\mathrm{O}_{3}\right)$, which cause acidic rain and smog, respectively. Although Turkey passed laws to reduce air pollution, air quality has been ebbing; Turkey is ranked 10th among the countries with the worst air quality (World Air Quality Index 2020).

On the arrival of COVID-19, industries were closed and cars were banned from the roads. It is hypothesized that the reduction of such activities led to improved air quality, saving over 7000 lives within 3 months of the country's lockdown. In this study, the changes in $\mathrm{PM}_{2.5}$ and ozone before and during lockdown are presented. Ozone changes were tracked because they represent the production of precursors such as $\mathrm{NO}_{\mathrm{x}}$ and $\mathrm{VCs}$. Additionally, the effect of ozone is easily seen through the formation of photochemical smog. Figure 1 depicts $\mathrm{PM}_{2.5}$ and $\mathrm{O}_{3}$ levels in Turkey in December 2019 (before COVID19), April 2020 (during lockdown), and May 2020 (reopening of some businesses). The average air quality index (AQI) based on these two parameters varied among provinces.

Apart from Ankara, the capital city of Turkey, the PM levels in the central region were below 125 . The central part of Turkey is sparsely populated and less industrialized compared to the rest of the country. The coastal areas elicited higher PM levels because of industrialization. Erzurum province had the highest AQI levels; the region has over 81 active industrial plants that include mining, textile, agriculture, and chemical plants. This makes the air quality in the area unhealthy for sensitive groups. During the lockdown, AQI improved across the entire country. Highly polluted regions like Erzurum registered an improvement in air quality. In December 2019, the average AQI was 171, while in April and May 2020, it was 66.7 and 68.5, respectively. The air quality 


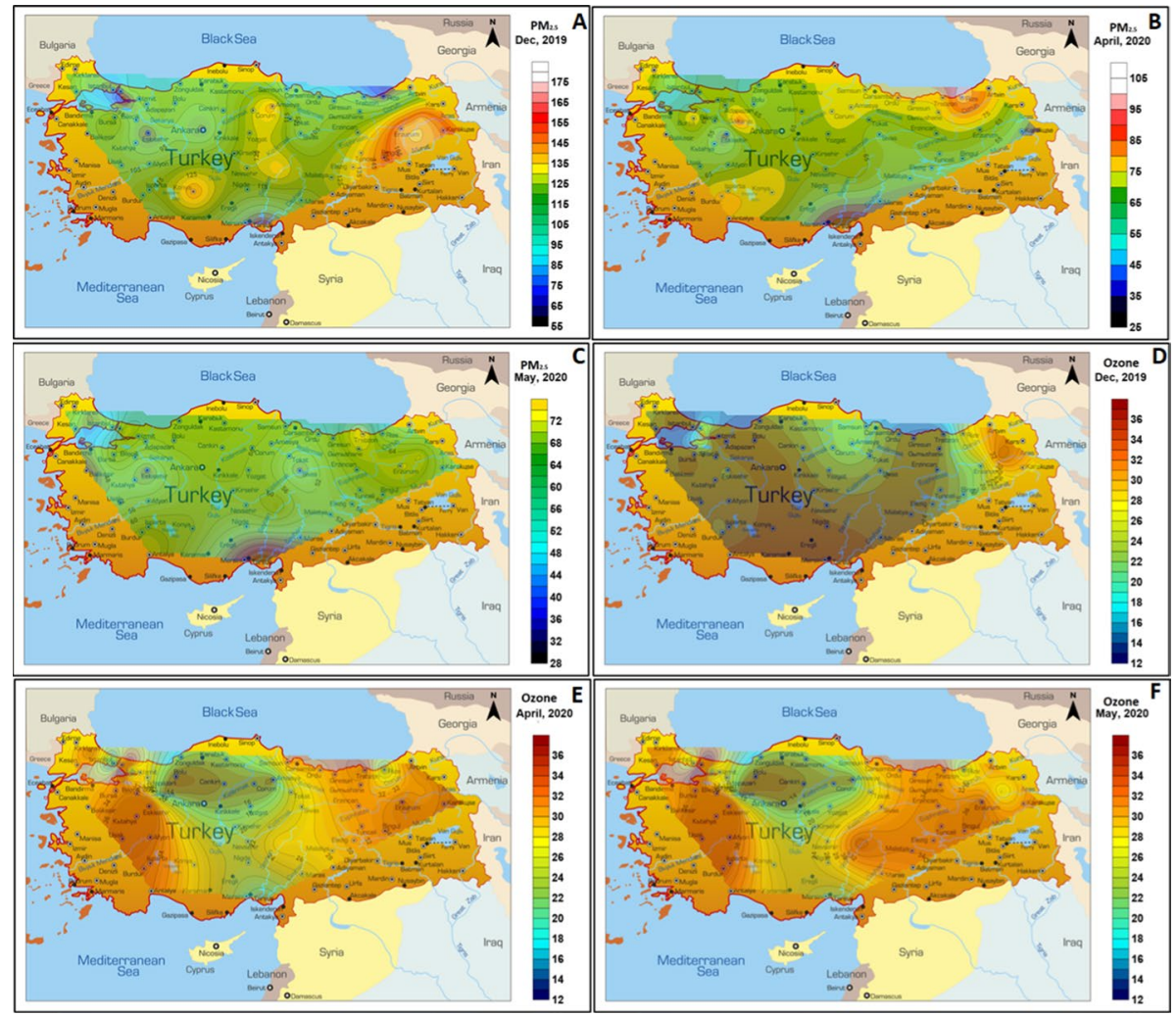

Fig. 1 AQI levels based on (a-c) $\mathrm{PM}_{2.5}$ and (d-f) ozone in December 2019, before the lockdown and in April and May 2020 during the lockdown

improved by over 2.5 times. The air quality dropped from an unhealthy to a moderate category. Although $\mathrm{PM}_{2.5}$ registered an improvement, ozone levels increased during the lockdown (Fig. 1).

Countries like Brazil, India, and China, also registered increases in ozone levels during the lockdown (Dantas et al. 2020; Sharma et al. 2020). Some studies have attributed the rise in the ozone to a decrease in $\mathrm{NO}_{\mathrm{x}}$ (Dantas et al. 2020). However, the decrease in $\mathrm{NO}_{\mathrm{x}}$ should plummet ozone levels since $\mathrm{NO}_{\mathrm{x}}$ is a precursor of ozone. Tropospheric ozone formation is facilitated by the presence of $\mathrm{NO}_{\mathrm{x}}, \mathrm{VCs}$, and sunlight, as shown in Eqs. (1)-(3). In the presence of sunlight, $\mathrm{NO}_{\mathrm{x}}$ splits, releasing an oxygen atom; this reaction is quickly reversed to form the parent compound, $\mathrm{NO}_{\mathrm{x}}$. However, the presence of VCs that can readily react with NO inhibit the backward reaction of NO and oxygen atoms (Finlayson-Pitts and Pitts 1993). The free oxygen atom can now promptly react with an oxygen molecule to form tropospheric ozone. Therefore, the increase in ozone levels cannot be attributed to $\mathrm{NO}_{\mathrm{x}}$ reduction, but rather to the decrease in $\mathrm{PM}$ levels. When the PM levels attenuate, more sunlight can penetrate the Earth's troposphere, facilitating the breakdown of $\mathrm{NO}_{\mathrm{x}}$ to $\mathrm{NO}$ and oxygen molecules. The increase in ozone is further escalated by the end of the winter season, as the number of sunny hours increase in Spring. The increase in sunny hours facilitates the formation of NO, 
Eq. (1). The ozone index in Turkey increased from 16.8 in December 2019, to 28.8 in April 2020, and to 29.7 by the end of May 2020. However, all of these increases are still categorized as good, based on the AQI.

$$
\begin{gathered}
\mathrm{NO}_{2} \underset{\text { sunlight }}{\Longleftrightarrow} \mathrm{NO}+\mathrm{O} \\
\mathrm{NO}+\mathrm{VCs} \longrightarrow \mathrm{VCs}-\mathrm{NO} \\
\mathrm{O}_{2}+\mathrm{O} \longleftrightarrow \mathrm{O}_{3}
\end{gathered}
$$

\section{Municipal wastewater and waste}

Water is a cardinal pillar of life; without it, life is impossible (Kajjumba et al. 2018, 2019). The survival duration of coronavirus ranges from $2 \mathrm{~h}$ to 9 days, depending on the prevailing conditions (World Health Organisation 2020). There are fears that COVID-19 can be transmitted in the water when a sick person releases contaminated water/waste from their homes. Australia was among the first the country to detect coronavirus in untreated wastewater (Ahmed et al. 2020). This raises concern to communities - if coronavirus can escape from water treatment facilities, then coronavirus will be here to stay. Chorine, ultraviolet rays, and ozone are promising technologies to treat coronavirus in water. However, all of these treatment techniques are effective in water with few suspended or dissolved solids (Ghernaout and Ghernaout 2020). Thus, if the virus finds a perfect hiding place, it can be released back into the environment. In addition, if the virus finds an ideal host that is resistant to chlorination or ozonation (e.g., cryptosporidium, adenovirus, or giardia), then effluent water is expected to contain coronavirus. In this study, the authors tracked the changes in wastewater treatment influent and effluent to detect any changes in chemical oxygen demand (COD) and total suspended solids (TSS) (Fig. 2).

Sakarya, Turkey, is one of the regions that has registered the highest number of COVID19 cases. Changes in the influent and effluent quality in one of the region's wastewater treatment plants were compared to changes in the Lüleburgaz wastewater treatment plant-an area that is less affected. The two plants have almost the same daily flowrate. Figure 2 elicits the changes in flowrate, COD, and TSS for both plants. Neither of the plants' flow rates changed during the coronavirus pandemic. However, the Lüleburgaz plant showed an increase in COD effluent during the lockdown. Overall, there was no significant change in TSS or COD in either plant. Since there were no changes in the plants' influents and effluents, it should be expected that the wastewater treatment managed any coronavirus contaminated water effectively. When the amount of medical waste generated in the same region was analyzed, the amount of waste generated only increased in April 2020; however, by May 2020, the generation had gone back to the normal trend. Because of the COVID-19 outbreak, only emergency cases were administered to in the hospitals; therefore, there was no spike in waste generation. 

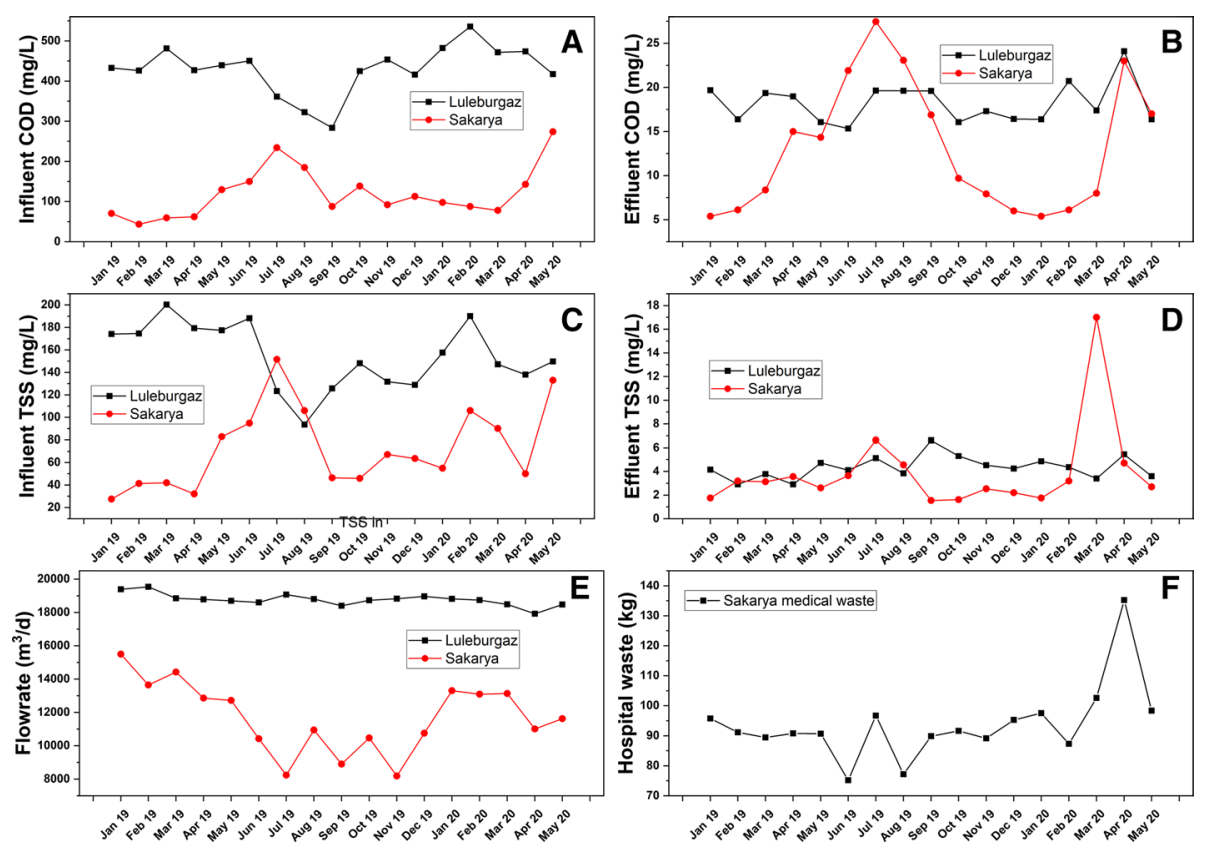

Fig. 2 Comparison of water quality for wastewater treatment plant (a-e) and (f) hospital waste generation before and during COVID-19

\section{Conclusion}

The post coronavirus economic crisis is evidence that Turkey is not ready for anything similar, let alone the combined set of climate impacted complications. Nothing is more severe than COVID-19 these days to an audience of all kinds. The effect of lockdown on the air quality, municipal wastewater, and hospital waste in Turkey from December 2019 to May 2020 was studied. $\mathrm{PM}_{2.5}$ had a maximum reduction in most cities, although ozone increased. The increase in ozone was due to a reduction in PM, which increased sunlight penetration, in-turn increasing the breakdown of $\mathrm{NO}_{\mathrm{x}}$. Therefore, it is possible to design emission control strategies that can improve air quality. There were no significant changes in flowrate, TSS, or COD levels in wastewater treatment plants studied, demonstrating that the treatment plants were not affected by the current pandemic. Nature is sending us a message, and COVID-19 has created the greatest opportunity to change some of our practices and find better ways to partner with nature.

Acknowledgements The authors would like to thank the Ministry of Environment and Urban Planning for providing National Air Quality data and Meagan Madariaga-Hopkins M.Ed of University of Nevada, Las Vegas, for editing her vulnerable suggestions.

\section{Compliance with ethical standards}

Conflict of interest The authors declare that they have no known competing financial interests or personal relationships that could influence the work reported in this paper. 


\section{References}

Ahmed, W., Angel, N., Edson, J., et al. (2020). First confirmed detection of SARS-CoV-2 in untreated wastewater in Australia: A proof of concept for the wastewater surveillance of COVID-19 in the community. Science of the Total Environment, 728, 138764. https://doi.org/10.1016/j.scitotenv.2020.13876 4.

Banik, R., Rahman, M., Sikder, T., \& Gozal, D. (2020). COVID-19 in Bangladesh: Public awareness and insufficient health facilities remain key challenges. Public Health, 183, 50-51.

Cattivelli, V., \& Rusciano, V. (2020). Social innovation and food provisioning during COVID-19: The case of urban-rural initiatives in the province of Naples. Sustainability, 12, 1-15.

Dantas, G., Siciliano, B., França, B. B., et al. (2020). The impact of COVID-19 partial lockdown on the air quality of the city of Rio de Janeiro, Brazil. Science of the Total Environment. https://doi.org/10.1016/j. scitotenv.2020.139085.

Finlayson-Pitts, B. J., \& Pitts, J. N. (1993). Atmospheric chemistry of tropospheric ozone formation: Scientific and regulatory implications. Air Waste, 43, 1091-1100. https://doi.org/10.1080/10731 61X.1993.10467187.

Gallardo, E. C., Carlos, J., De Arroyabe, F., \& Arranz, N. (2020). Preventing internal COVID-19 outbreaks within businesses and institutions: A methodology based on social networks analysis for supporting occupational health and safety services decision making. Sustainability, 12, 1-16. https://doi. org/10.3390/su12114655.

Ghernaout, D., \& Ghernaout, B. (2020). Controlling COVID-19 pandemic through wastewater monitoring. Open Access Library Journal, 7, 1-20. https://doi.org/10.4236/oalib.1106411.

Johns Hopkins University. (2020). COVID-19 Dashboard by the Center for Systems Science and Engineering (CSSE) at Johns Hopkins University (JHU). In Johns Hopkins University. https://coronavirus.jhu. edu/map.html. Accessed 30 June 2020.

Kajjumba, G. W., Aydın, S., \& Güneysu, S. (2018). Adsorption isotherms and kinetics of vanadium by shale and coal waste. Adsorption Science and Technology, 36, 936-952. https://doi.org/10.1177/0263617417 733586.

Kajjumba, G. W., Yıldırım, E., Aydın, S., et al. (2019). A facile polymerisation of magnetic coal to enhanced phosphate removal from solution. Journal of Environmental Management, 247, 356-362. https://doi. org/10.1016/j.jenvman.2019.06.088.

Lee, A. (2020). Wuhan novel coronavirus (COVID-19): Why global control is challenging? Public Health, 179, A1-A2.

Osra, F. A., \& Kajjumba, G. W. (2020). Landfill site selection in Makkah using geographic information system and analytical hierarchy process. Waste Management and Research, 38, 245-253. https://doi. org/10.1177/0734242X19833153.

Polivka, B. J. (2018). The Great London Smog of 1952. American Journal of Nursing, 118, 57-61. https:// doi.org/10.1097/01.NAJ.0000532078.72372.c3.

Sawicki, S. G., \& Sawicki, D. L. (1986). Coronavirus minus-strand RNA synthesis and effect of cycloheximide on coronavirus RNA synthesis. Journal of Virology, 57, 328-334. https://doi.org/10.1128/ jvi.57.1.328-334.1986.

Sharma, S., Zhang, M., Anshika, J. G., et al. (2020). Effect of restricted emissions during COVID-19 on air quality in India. Science of the Total Environment. https://doi.org/10.1016/j.scitotenv.2020.138878.

Shirbandi, K., Barghandan, S., Mobinfar, O., \& Rahim, F. (2020). Inactivation of coronavirus with ultraviolet irradiation: What? How? Why? SSRN Electronic Journal. https://doi.org/10.2139/ssrn.3571418.

Temiz Hava Hakkı. (2019). Right to clean air platform. In Temiz Hava Hakkl. https://www.temizhavahakki. com/english/.

Wang, N., Li, S. Y., Yang, X. L., et al. (2018). Serological evidence of bat SARS-related coronavirus infection in humans, China. Virologica Sinica, 33, 104-107.

Wong, G., Liu, W., Liu, Y., et al. (2015). MERS, SARS, and Ebola: The role of super-spreaders in infectious disease. Cell Host and Microbe, 18, 398-401.

World Air Quality Index. (2020). World's air pollution: Real-time air quality index. In World air quality index. https://aqicn.org/contact/. Accessed 22 May 2020.

World Health Organisation. (2020). Water, sanitation, hygiene and waste management for the COVID-19 virus. World Heal Organ (pp. 1-9).

Publisher's Note Springer Nature remains neutral with regard to jurisdictional claims in published maps and institutional affiliations. 


\section{Affiliations}

Serdar Aydın ${ }^{1}\left[\right.$. Betina Assumpta Nakiyingi ${ }^{2} \cdot$ Cengiz Esmen $^{3} \cdot$ Sinan Güneysu ${ }^{1}$. Meena Ejjada ${ }^{4}$

Serdar Aydın

saydin@istanbul.edu.tr

1 Department of Environmental Engineering, Istanbul University-Cerrahpaşa, Avcilar Campus, Avcrlar, 34320 Istanbul, Turkey

2 Department of Geomatics and Land Management, Makerere University, Kampala, Uganda

3 Era Environmental Technologies Inc., Aydoğdu Köyü Mevkii 17. Cadde No: 3 Merkez, Erzincan, Turkey

4 Department of Civil and Environmental Engineering and Construction, University of Nevada, Las Vegas, 4505 S. Maryland Pkwy, Las Vegas, NV 89154, USA 